Original Research Paper

\title{
Making Decision About Vaccines for Minors. Health Policies, Individual Choices and Legislative Interventions: The Italian Case
}

\author{
Lorena Forni \\ School of Law, University of Milano - Bicocca, Milano, Italy
}

\section{Article history}

Received: 19-09-2019

Revised: $29-10-2019$

Accepted: 31-10-2019

Email: lorena.forni@unimib.it

\begin{abstract}
In Italy, as in other Countries around the world, there is a strong debate about vaccines for children. This paper highlights the legal, ethical and social reasons for the mandatory vaccination practice, both in public decision-making and in private choices. In Italy there are no penalties for non-vaccination. Starting from important recent institutional and legal interventions, attention will be given to arguments in favor of combating deviant behavior. We will therefore propose arguments and reflections, to clarify an issue that is often very confusing, especially in the era of the global health problems.
\end{abstract}

Keywords: Vaccines, Right to Health, Freedom, Care, Law, Ethics, Bioethics

\section{Introduction}

Addressing the issue of vaccines for children is never easy. Law and scientific data matter, but personal convictions, irrational fears and ideological conditioning come into play as well. This topic investigates personal or family choices, public decision - making process, different concepts of dignity with the purpose to critically reflect on our idea of freedom of choice and freedom of care, in relation to public health policies.

According to latest W.H.O. official reports (W.H.O., 2018) the situation concerning the vaccines for minors is worrying. For example, data collected about the measles infection among children have shown that about 50,000 cases were found in Europe from January until October 2018: It is also to stress that around the same time the number of cases recorded in the whole African continent were more than double (Larson, 2018).

We cannot openly talk about choices of criminal public policy; we cannot even talk about criminally relevant individual behaviors. Under current legislation, around the world, we are not provided for criminal penalties for failure to vaccinate children.

However, we should reflect on the health consequences for individuals and the community, which would occur if most of the population refused to have their children vaccinated.

The "vaccine crisis" for children is a global phenomenon, which has different roots, reasons and consequences depending on the Country analyzed, but that concerns a common danger to the health of all of us.

\section{Irrational Reasons and Legal Arguments in the Discussion on Vaccines in Italy}

In developed countries some parents have decided not to provide routine vaccinations for their children, while in many developing countries there are inadequate rates of vaccination for various reasons (W.H.O., 2019a). The consequences for children and members of the community in which they live, can be significant and even tragic. Although some parents may worry that vaccines will harm their children, there is a broader ethical consideration for vaccination that parents and policy makers should consider. This consideration has four components: benefits and harms, best interests, community benefits and justice. This reflection should be central to deliberations about vaccination by parents and policy makers.

The relationship between the condition of minors and the obligation of vaccination should not be managed on the basis of common feeling.

On the contrary, as in the case of health problems (both private and public), these policies and interventions should identify trends - or counter trends in order to point out adequate legal instruments to manage complex health and social dynamics. 
Nature, in January 2018, published an editorial that brought attention to the French reality (AA. VV., 2018). In this Country, from January 1, 2018, a provision came into force, concerning the mandatory vaccination for minors, very similar to the Italian one. This French law (Code de Santé Publique, 2017) reiterated that widespread immunization is a vital tool for public health, but that other actions should not be considered secondary, to obtain satisfactory results (Ward et al., 2018; Ollivier-Yaniv, 2017). This was affirmed to placate the strong political, legal and institutional polemics, that have occurred beyond the Alps, as indeed in Italy (Cocchio, 2016). In this regard, the importance of timely information campaigns to be provided to the public, the unavoidability of the support of the scientific community and the need to introduce moments of confrontation and active involvement of the families was recalled.

In anticipation of the good reasons highlighted by Nature regarding the obligation of vaccination for minors, in Italy, for a long time, a solid institutional front has emerged. In fact, since 2015, the Italian National Committee for Bioethics (CNB) had taken a position in favor of the vaccination practice for minors with the motion The importance of vaccinations (Comitato Nazionale di Bioetica, 2015). Furthermore, last January 18, 2018, the Italian Constitutional Court, with judgement no. 5 of 2018, was able to clarify the arguments on the assessment of legitimacy and reasonableness with respect to the obligation of vaccinations (Italian Constitutional Court, 2018), as a condition for access to kindergartens and primary schools, as required by Italian law n. 119 of 2017 (Parlamento italiano, 2017). This legal intervention has made mandatory vaccines for polio, diphtheria, tetanus, hepatitis B, whooping cough, Haemophilus influenzae type B, measles, rubella, mumps and varicella.

According to the Court, the Italian legislator has not overstepped its role in terms of the obligation to vaccinate, precisely because it has implemented, in a particular context, the constitutional rules, namely Articles 32 and 2 of the Italian Constitution. Article 32 states that: «The Republic safeguards health as a fundamental right of the individual and as a collective interest and guarantees free medical care to the indigent. No one may be obliged to undergo any health treatment except under the provisions of the law. The law may not under any circumstances violate the limits imposed by respect for the human person».

Whenever we talk about "fundamental rights" we refer to the definition denoting to all the subjective rights, confirmed (mainly) at the constitutional level, that universally pertain to every human being as endowed with the status of person, or citizen, or person with legal capacity (Ferrajoli, 2013). Similarly, it is appropriate to define subjective rights as every positive (to achieve services) or negative (to avoid harm or impediment) expectation ascribed to a subject by laws (Ferrajoli, 2014).

In fact, Italian vaccine measures not only aim at guaranteeing the (fundamental) right to health in its subjective dimension (Article 32), but also the public and social interests protected. Limiting situations and conditions of contagion is vital, through one or more acts (legal and social) inspired by those binding obligations of political and social solidarity, prescribed also in Article 2 of Italian Charter.

The Italian Constitutional Court then specified that the law that requires health treatment is not incompatible with art. 32 of the Constitution if treatment is directed not only to improve or preserve the state of health of those subjected to it, but also to preserve the health of third parties; moreover, if treatment does not negatively affect the state of health of the person who is obliged to do so, except for those consequences which appear normal and, therefore, tolerable; and, finally, if in the event of damage, the payment of an fair indemnity in favor of the injured person is envisaged, regardless of the parallel compensation protection.

The right to health is not an opinion; it cannot be accepted or rejected as any idea about the world.

Parents and individuals may have a personal conception of health, however, they may not affect the exercise of a subjective right to health of their minor children, to the point of harming them, as in the case of non-vaccination.

\section{The Social and Juridical Reasons in Favor of the Mandatory Juvenile Vaccination}

The Italian legislative choice of 2017 can be considered approved in the light of the ethical, social and juridical rights and criteria underlying the question: In fact, the fundamental right to health, understood in its dimensions, individual and collective, ex art. 32 of the Italian Constitution, has been well balanced with respect to the best interests of the minor. To be honest, this was the criterion most emphasized by the Constitutional Court, which specified that the best interest of children must «pursue first of all, in exercising the right-duty of parents to adopt the appropriate conduct to protect the health of children (articles 30 and 31 of the Constitution), ensuring that this freedom does not lead to choices that are potentially detrimental to the child's health».

The legislator has used its discretion in a balanced way, «in the choice of ways to ensure effective prevention from infectious diseases, being able to select the technique of recommendation, sometimes that of the obligation, as well as, in the second case, calibrate various measures, including sanctions, aimed at 
ensuring the effectiveness of the obligation». This discretion must be exercised in strict reference to the various health and epidemiological conditions, ascertained by the authorities in charge and acquisitions of medical research, constantly evolving, which must adequately guide the legislator in the exercise of his choices. The Court to highlight also that as the general epidemiological and social conditions change, this choice can be reevaluated and reconsidered. In Italy, since the 1930s (Parlamento italiano, 1939), have been introduced measures to establish general vaccination obligations for the pediatric population. We therefore had a gradual extension of compulsory vaccinations for minors, culminating, to date, with the law n. 119 of 2017.

We will not enter here into the merits of critical positions in the field, exemplary as "anti-vaxxers" or "free vaxxers" positions (Phillips, 2017), but we will try to solve the problem of the rather tangled discourse: "freedom of care and freedom of choice" about vaccines.

Taking note of the existing law, the current debate on vaccines revolves around two issues. The first can be summarized as follows: "Are children really vulnerable, chiefly with regard to vaccines?" And the second question could be: "Why and for which reasons should we vaccinate children?"

\section{Are Children Really Vulnerable?}

Regarding the first question, minors are vulnerable according to two meanings. In a first meaning, because they have the vulnus of not being able to decide autonomously for their own health.

In a second sense, they are vulnerable due to the fact that they are the recipients of choices made by others. Not always, as in the case of vaccines, the choices made take into account their best interest.

Moreover, an initial answer, about the second question, could be: "Children vaccination it's a duty, because it is so prescribed by law". It would be a secundum ius choice. However, we could try to tackle the problem from another perspective and recall some fertile intuitions of Sen $(1987 ; 1999 ; 2009 ; 2002 ; 2010$; 2012) on the issue of justice of public and individual health issues. Sen argues, in fact, that what is considered fair, or just (Forni, 2016), both for individuals and for public issues (and must be specified, even for public health), is generally estimated in reference to the general advantage that can be obtained. Sen also proposes an original redefinition of the term "advantages", or capabilities. According to Sen (2009), estimating what is an "advantage" means identifying what is a "resource" and, at the same time, means identifying "what is worth doing/being". Then, we could ask whether vaccinating minors is a choice worth making, whether it is an advantage for the players involved. In short, child vaccination is also an acceptable choice, to be preferred, or broadly speaking, is a "just" choice?

\section{Arguments against Vaccines on Minors. Critical Remarks}

Those who refuse vaccines for their children, do so based on various topics. It supports, for example, the hygienic conditions of society and hospital environments (i.e., for tetanus) or artificial passive immunity (i. e. achieved not through the vaccine, but by antibiotics and by the administration of antibodies, as in the case of diphtheria) they would be important contributors to having positively impacted on the lesser diffusion of the pathogens considered (Mogensen et al., 2017); therefore, the scope of vaccine efficacy should be greatly reduced. In other cases, there is strong evidence that would tend to show that the qualification of the danger of some specific diseases, such as chickenpox, for example, should be rethought.

However, the biggest fear concerns other problems. Parents fear to expose children to serious consequences, to serious illnesses (such as cancer or autoimmune diseases). They are afraid of the relationship between vaccines and autism (but it would be better to say: Autism spectrum disorder). This is not an irrelevant clarification, since the c.d. "disorders" associated with autism are many, different and are not the same in all subjects and because the autistic syndrome is one of the most complex of those emerging in children's developmental age (Costantino, 2018). There is talk of the autistic spectrum precisely because it denotes a wide range of behaviors, referable to serious or generalized compromises of the cerebral areas of development, which involve difficulties in communication skills and social interaction (for example, we talk about the lack of reciprocity for social and emotional communication and for nonverbal communication used for social purposes; we also talk about the difficulties of creating and maintaining social ties appropriate to the general level of development).

Some recent researches do not exclude that autism may also be related to genetic or environmental factors, not investigated and not timely diagnosed (Ramaswami and Geschwind, 2018.) However, since it is a syndrome whose causes are not yet clear and are not identified certainty, at the scientific level, new lines of research are being undertaken, as emerged from some studies, which have investigated, for example, a possible correlation between syndrome autistic disorder and vitamin D deficiency (Sotodehasl et al., 2018).

We don't know much about autism spectrum disorder, but we can say that there are no arguments to consider it an effect of vaccines given to minors. 


\section{"Freedom of Choice" and "Freedom of Care": Misunderstood Expressions}

While the detractors of the vaccine practice, in one hand, claim to have data that would warn about the consequences of certain vaccines or criticize some uses; on the other hand, however, we have many, if not more numerous, researches, which refute or strongly limit the conclusions of those referred to justify a choice against the vaccination for children.

The issue of vaccination, as emphasized by Nature, is not and must not be reduced to the contention of enemy "supporters", precisely because it concerns choices that are relevant both at the individual and collective level.

The rejection of vaccinations on minors, however, is often related to an unspecified "freedom of choice and freedom of care". From the legal and social point of view, we must remember that health is indeed a fundamental and personal right, but it is also an interest of the community. For this reason, in particular cases determined by law, constraints are placed on the exercise of autonomous choices. The vaccines on minors fall into this second category and, therefore, are not qualified in our system as "free choice" treatments, in the sense that parents have not the right to opt or not for administration to their children. An adult and capable subject has freedom of choice and care over himself, that is, can make for himself all the choices he wants, even at the risk of his own health and life (but as long as he does not harm other people's legal positions and does not cause harm to thirds). Differently, minors cannot selfdetermine with regard to treatment choices, choices that, in the case of vaccines, affect not only them, but also have potential serious effects on the generality of the members of society. Consequently, the choice of those who, in the name of a misunderstood freedom, decide not to vaccinate their children, cannot be justified. Parents (or legal guardians) are required to make the right choice. Not subjecting a child to a vaccine, in addition to violating a legal obligation, exposes the child to a serious risk to health, a risk that indirectly weighs on all those (minors and not) who come into contact with him.

\section{Is a Right and Responsible Choice to Vaccinate Minors? Short Concluding Notes}

Despite what has been highlighted so far, some sceptics may wonder, again, if vaccinating minors is a serious and necessary choice that is worth doing. The answer, in the affirmative, can be justified on the basis of further arguments. First of all and as recalled by the Italian Constitutional Court and also by most authoritative national and international legal and ethical institutions, their best interests are made, because in the face of very low risks, there is the advantage of immunizing the subjects compared to a wide range of pathologies. Moreover, improved socio-sanitary or hygienic conditions alone do not prevent viral or bacterial diffusion: They may be concurrent and further conditions to favor healthy environments, but they cannot represent a valid alternative to vaccination. Furthermore: The herd immunity is possible, to the benefit of the unvaccinated, only if there is a high number of virtuous behaviors, put in place by adults, that make their children vaccinated not only in the name of a personal or family choice, but because they are aware of being called responsibly to do the good of their children and, indirectly, not to harm the children of other members. If in recent decades the vaccines had produced poor results, today the problem of their use would not arise. This is a paradoxical situation, because despite the success of previous vaccination campaigns, their effectiveness is continually questioned. However, the current data do not seem to indicate that, with regard to vaccines on children, a possible choice not related to the obligation, but based on persuasion, has produced good results. We should therefore ask whether leaving the choice concerning the vaccinations on minors to the (arbitrary) decision of the parents is really an acceptable option. We must remember that, in Italy, when we refer to "freedom of care", if this expression is not clarified or specified, we are faced with highly problematic situations, as was, for example, the "Di Bella" Italian case and the "Stamina" case too (Comitato Nazionale per la Bioetica, 2016; Soofi, 2018).

It is not always a question of invoking the precautionary principle. This principle prescribes to neutralize or minimize the risks to human health, even if not fully ascertained, on the basis of particular and concrete conditions (Wiener, 2018). Actually, it is a matter of understanding that not all choices can be justified, in the name of self-determination and freedom, if the contents are not specified and if the possible consequences are not taken care of.

We should seriously think about the consequences of a lack of mass vaccination (in children).

Nowadays, in Italy, in Europe and in many other countries around the world, we have no criminal sanctions, for fear of fueling a social conflict on this issue.

However, a mass vaccination not carried out would put at risk the health - and in some cases - the lives of others, especially the weakest ones. We should remember children with immunodeficiency, or the chronically ill who cannot undergo vaccinations.

Health is a protected good, in some legal systems it is also constitutionally protected. In Italy, it is also a fundamental right of every individual and a collective interest.

Unfortunately, the trend towards non-vaccination is not only national or European; on the contrary, it is taking on a global dimension (Belseck, 2019; W.H.O., 
2019b). Examples of this are the measles problems in children in the United States (Cantor, 2019), but also in Great Britain (Public Health England, 2019), or in Venezuela (Paniz-Mondolfi et al., 2019) and Eastern Europe (Pelčić et al., 2016).

We should therefore seriously consider what we are willing to renounce, in terms of health and life safety, if we do not oppose deviant behavior imposed on our minor children.

We must perhaps understand that we need legal tools that are more incisive than administrative and private law sanctions.

We should think carefully about which are the most appropriate tools for decision-making, both at public and individual level, without distorting, at the same time, the idea of freedom.

As many scholars have said, such as Sen (2009; 2012) at the international level and Scarpelli (1987) in Italy, freedom entails responsibility, that is to say it commits us to take into consideration «the foreseeable consequences of actions and the instrumentality of the underlying principles, capable of justifying lines of conduct with respect to desired ends» (Scarpelli, 1987).

Recalling this words, we should consider vaccination for children a practice that is not only dutiful and beneficial, both on an individual and collective level, but also a right choice, a choice, that is, that must be worth doing in the era of globalization.

\section{Acknowledgement}

This article is based on a speech given in July 2019 at the 29th World Congress of the International Association for Philosophy of Law and Social Philosophy, held in Lucerne, Switzerland. I would like to thank my colleagues and students for the interesting discussions.

\section{Ethics}

This manuscript is based on scientific and legal data. However, the author is willing to discuss any ethical issues that may arise after the publication of this manuscript.

\section{References}

AA. VV., 2018. Vaccine boosters. A new French law that makes immunizations mandatory is not the only way to improve. Nature, 553: 249-250. DOI: $10.1038 / \mathrm{d} 41586-018-00660-y$

Belseck, N., 2019. Anti-Vaxxers a top threat to global health. Medical Chronicle, 2: 1 - 4ISSN 2617-9385.

Cantor, J.D., 2019. Mandatory measles vaccination in New York City-reflections on a bold experiment. New England J. Med., 381: 101-103. DOI: $10.1056 /$ NEJMp1905941
Cocchio, S., 2016. A postmarket safety comparison of 2 vaccination strategies for measles, mumps, rubella and varicella in Italy. Human Vaccines Immunotherapeut., 12: 651-654. DOI: 10.1080/21645515.2015.1101198

Code de Santé Publique. France, 2017. Article L. 3111-2.

Comitato Nazionale per la Bioetica, 2016. Single patient care and non-validated treatment (The so-called "compassionate use"). Jahrbuch für Wissenschaft und Ethik, 20: 385-412.

DOI: $10.1515 /$ jwiet-2016-0125

Comitato Nazionale di Bioetica, 2015. L'importanza delle vaccinazioni.

Costantino, J.N., 2018. Deconstructing autism: From unitary syndrome to contributory developmental endophenotypes. J. Int. Rev. Psychiatry, 30: 18-24. DOI: $10.1080 / 09540261.2018 .1433133$

Ferrajoli, L., 2013. Dei diritti e delle garanzie. (About Rights and Guarantees). 1st Edn., Il Mulino, Bologna pp: 189.

Ferrajoli, L., 2014. La democrazia attraverso i diritti. (Democracy Through Law). Laterza, 1st Edn., Roma - Bari, pp: 285.

Forni, L., 2016. La Sfida della Giustizia in Sanità. Salute, Equità, Risorse. Giappichelli, Torino. 1st Edn., ISBN-13: 978-88-921-0329-0, pp: 248.

Italian Constitutional Court, 2018. Italian Constitutional Court. Judgement no. 5.

Larson, H.J., 2018. The state of vaccine confidence. Lancet, 392: 2244-2246. DOI: $10.1016 / \mathrm{S} 0140-6736(18) 32608-4$

Mogensen, S.W., A. Andersen, A. Rodrigues, C.S. Benn and P. Aaby, 2017. The introduction of diphtheriatetanus-pertussis and oral polio vaccine among young infants in an Urban African Community: A natural experiment. EBioMedicine, 17: 192-198. DOI: 10.1016/j.ebiom.2017.01.041

Ollivier-Yaniv, C., 2017. La vaccination, ça se discute? Le rapport sur la politique vaccinale, espace polyphonique inédit. Mots. Les Langages du Politique, 114: 117-133. DOI: 10.4000/mots.22815

Paniz-Mondolfi, A.E., A. Tami, M.A. Grillet and M. Márquez. 2019. Resurgence of vaccine-preventable diseases in venezuela as a regional public health threat in the Americas. Emerg. Infect. Dis., 25: 625-632. DOI: 10.3201/eid2504.181305

Parlamento Italiano, 2017. Legge n. 119/2017. Conversione in legge, con modificazioni, del decreto-legge 7 giugno 2017 , n. 73 , recante disposizioni urgenti in materia di prevenzione vaccinale.

Parlamento Italiano, 1939. Legge n. 891/1939. Obbligatorietà della vaccinazione antidifterica.

Pelčić, G., S. Karačić and L. Tomašević, 2016. Religious exception for vaccination or religious excuses for avoiding vaccination. Croatian Med. J., 57: 516-521. DOI: $10.3325 / \mathrm{cmj} .2016 .57 .516$ 
Phillips, T., 2017. The pseudoscience of anti-vaccination groups. Stellar Undergraduate Res. J. Oklahoma City, 11: 15-18.

Public Health England, 2019. UK measles and rubella elimination strategy.

Ramaswami, G. and D.H. Geschwind, 2018. Genetics of autism spectrum disorder. Handbook Clin. Neurol., 147: 321-329.

DOI: 10.1016/B978-0-444-63233-3.00021-X

Scarpelli, U., 1987. La Bioetica. Alla ricerca dei principi. Biblioteca delle libertà, 22: 31-31.

Sen, A., 1987. Commodities and Capabilities. 1st Edn., Oxford University Press, Oxford, ISBN-13: 9780195650389, pp. 89.

Sen, A., 1999. Development as Freedom, 1st Edn., Knopf, New York, ISBN-10: 0375406190, pp: 366.

Sen, A., 2009. The Idea of Justice. ISBN-13: 9780674060470 , pp: 496

Sen, A., 2002. Globalizzazione e Libertà, Mondadori. 1st Edn., Milano, ISBN 9788804519485, pp: 160

Sen, A., 2010. La Disuguaglianza. 1st Edn., Il Mulino, Bologna, ISBN-13: 978-88-15-13417-2, pp: 304

Sen, A., 2012. L'Azione Giusta. 1st Edn., Ediesse, Rome, ISBN-13: 9788823016521, pp: 123.
Soofi, H., 2018. Mode 2 knowledge production in the context of medical research: A call for further clarifications. J. Bioethical Inquiry, 15: 23-27. DOI: $10.1007 / \mathrm{s} 11673-017-9822-9$

Sotodehasl, N., M.R. Tamadon and F. Malek, 2018. Vitamin D deficiency and autism; a review on recent findings. J. Parathiroid Desease, 6: 7-12. DOI: $10.15171 /$ jpd.2018.04

Ward, J.K., J. Colgrove and P. Verger, 2018. Why France is making eight new vaccines mandatory. Vaccine, 36: 1801-1803.

DOI: 10.1016/j.vaccine.2018.02.095

W.H.O., 2018. Measles and rubella surveillance data. W.H.O.

W.H.O., 2019a. Ten threats to global health. Vaccine Hesitancy. W.H.O.

W.H.O., 2019b. Measles magadagascar. Emergencies Preparedness, Response.

Wiener, J.B., 2018. Precautionary Principle. In: Elgar Encyclopedia of Environmental Law, Krämer, L. and E. Orlando (Eds.), Edward Elgar Publishing Limited, University of Sussex, Cheltenham Glos, ISBN-13: 9781785365652, pp: 174-185. 